www.jmscr.igmpublication.org Impact Factor 5.244

Index Copernicus Value: 83.27

ISSN (e)-2347-176x ISSN (p) 2455-0450

crossref DOI: _https://dx.doi.org/10.18535/jmscr/v4i12.114

Journal Of Medical Science And Clinical Research

\title{
Comparison and Evaluation of the Outcome of Fistulotomy Vs Fistulectomy Technique in Treatment of Low Fistula in Ano
}

\author{
Authors \\ Atul Kumar Vyas ${ }^{1 *}$, Amit Katlana ${ }^{2}$, Abhinav Rathi ${ }^{3}$, Prateek Porwal ${ }^{4}$, Rahul Jain ${ }^{5}$ \\ Praneeth Etta ${ }^{6}$ \\ ${ }^{1,2}$ Associate Professor, ${ }^{3-6}$ Postgraduates Department of Surgery IMCHRC, Indore \\ *Corresponding Author \\ Atul Kumar Vyas \\ Email:dr.atulkvyas@gmail.com
}

\begin{abstract}
Background: Fistula in ano is common surgical condition that is being treated by different surgical modalities. Aim of the study was to compare and evaluate the outcome of fistulotomy and fistulectomy technique in treatment of low fistula in ano.

Material and Method: This prospective study was conducted in department of surgery Index Medical College Hospital and research centre, indore from June' 14 to July '16. This study included 75 patients of low fistula in ano admitted during the study period .out of these 38 patients underwent fistulotomy (group A) and 37 patients underwent fistulectomy (group B). The two techniques were compared in terms of healing time, post operative pain, hospital stay, complication, recurrence and outcome.

Result: The average age of study group was 45.2 years with male: female ratio 7.3:1. post operative pain was $2.16 \pm 1.02$ days for group A (fistulotomy) and $5.95 \pm 3.00$ days for group B (fistulectomy).

4 (Four) patients of group A $(10.52 \%)$ had wound infection while 15 patients of group B $(40.52 \%)$ had wound infection.

post operative wounds in group A healed earlier in comparision to group B wounds $(28.55 \pm 5.717$ vs 48.54 \pm 12.43 days,$P=0.0001)$. The mean hospital stay of group $A$ was $2.86 \pm 1.78$ days, while for group $B$ was $4.32 \pm 2.22$ days . No incidence of anal incontinence in both groups. Recurrence developed in 2 patients out of $38(5.3 \%)$ of fistulotomy and 7 patients out of 37 (18.9\%) following fistulectomy.

Conclusion: Fistulotomy can be recommended as a standard surgical procedure in the treatment of low anal fistula for the merits of early wound healing, less post operative pain, lower rates of wound infection, early hospital discharge and lesser incidence of recurrence in comparison to that of fistulectomy.
\end{abstract}

Keywords: Fistulotomy, Fistulectomy, Low Anal Fistula.

\section{Introduction}

A fistula-in-ano is a hollow tract lined with granulation tissue connecting a primary opening inside the anal canal or rectum to a secondary opening in the perianal skin. Secondary tracts may be multiple and form the same primary opening. Fistula in ano is common surgical condition that is being treated by different surgical modalities. 


\section{Material and Method}

On approval from ethical committee, this prospective study was conducted in department of surgery Index Medical College Hospital and research centre, Indore from June ' 2014 to July '2016. This study included 75 patients of low fistula in ano admitted during the study period, out of these 38 patients underwent fistulotomy (group A ) and 37 patients underwent fistulectomy (group B). All low anal fistulas with any age, any gender was included in our study, only high fistula, previously carcinoma, irradiated or severely sick patient were excluded. Written consents were obtained from all patients before the study. The steps of both operative interferences were explained to all patients. Cases were operated randomly by two different procedures. The two techniques were compared in terms of healing time, post operative pain, hospital stay, complication, recurrence and outcome.

\section{Result}

In the period of 2 year, the common age group affected by fistula in ano found to be 31 to 50 years. The youngest patient was 26 years of age and the oldest 75 years

Table 01 : Showing Age Incidence

\begin{tabular}{|l|c|c|}
\hline $\begin{array}{l}\text { Age group } \\
\text { (in years) }\end{array}$ & $\begin{array}{c}\text { No. of } \\
\text { cases }\end{array}$ & Percentage \\
\hline 20 to 30 & 8 & 10.67 \\
31 to 40 & 27 & 36.00 \\
41 to 50 & 25 & 33.33 \\
51 to 60 & 7 & 9.33 \\
Above 61 & 8 & 10.67 \\
\hline Total & 75 & 100 \\
\hline
\end{tabular}

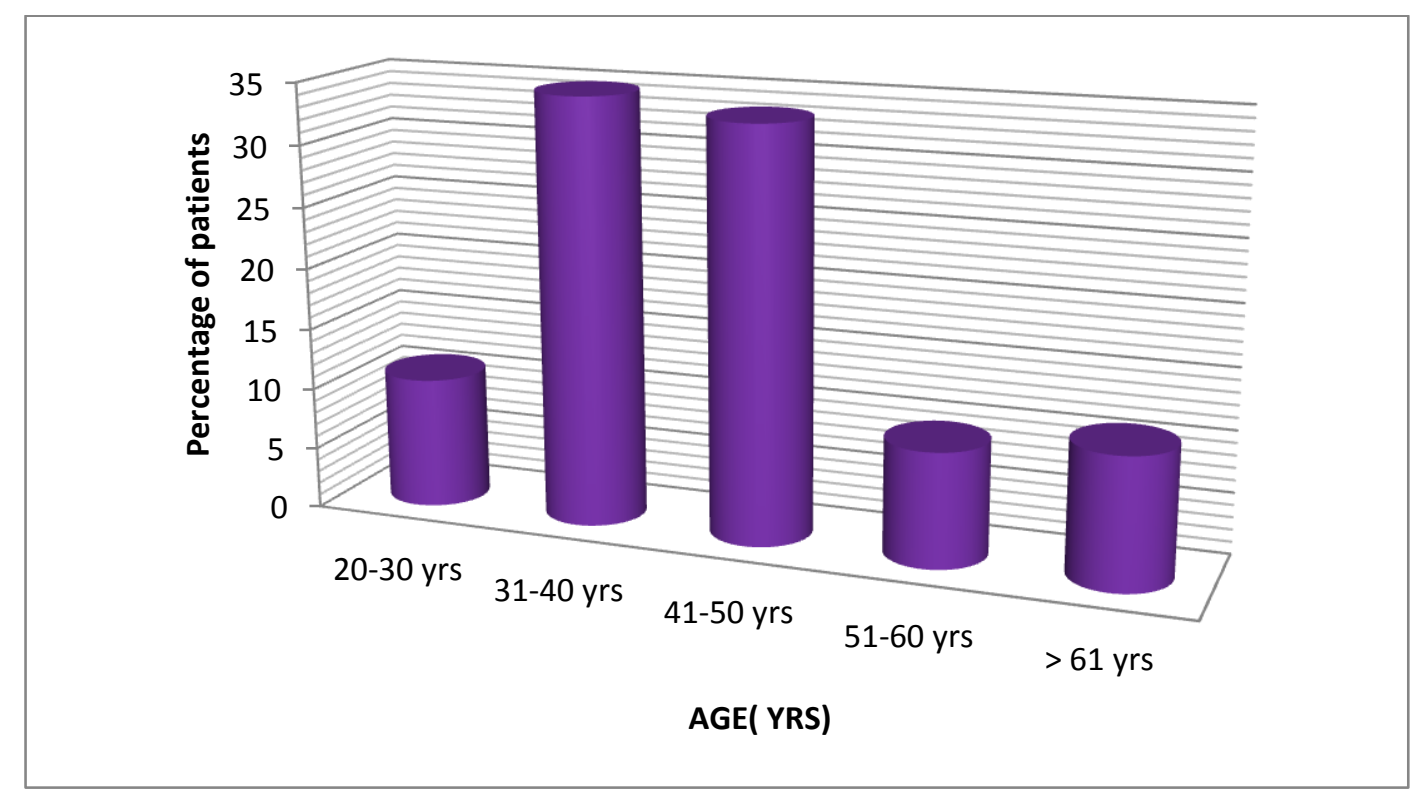

Graph 01 : Showing age incidence

Post operative pain was $2.16 \pm 1.02$ days for group A (fistulotomy) and $5.95 \pm 3.00$ days for group B (fistulectomy). The mean value of two groups are compared and as $\mathrm{p}>0.05$ the mean value of Group A is significantly low than that of Group B.

Table 02 : Post operation pain duration in various groups

\begin{tabular}{|l|c|c|c|c|c|c|}
\hline Groups & $\begin{array}{c}\text { Minimum } \\
\text { duration of pain } \\
\text { (days) }\end{array}$ & $\begin{array}{c}\text { Maximum } \\
\text { duration of pain } \\
\text { (days) }\end{array}$ & $\begin{array}{c}\text { mean duration of } \\
\text { pain } \\
\text { (days) }\end{array}$ & SD & T & P Value \\
\hline Group A & 2 & 6 & 2.16 & 1.02 & & \\
\hline Group B & 3 & 20 & 5.95 & 3.00 & 6.469 & 0.00 \\
\hline
\end{tabular}

T test 


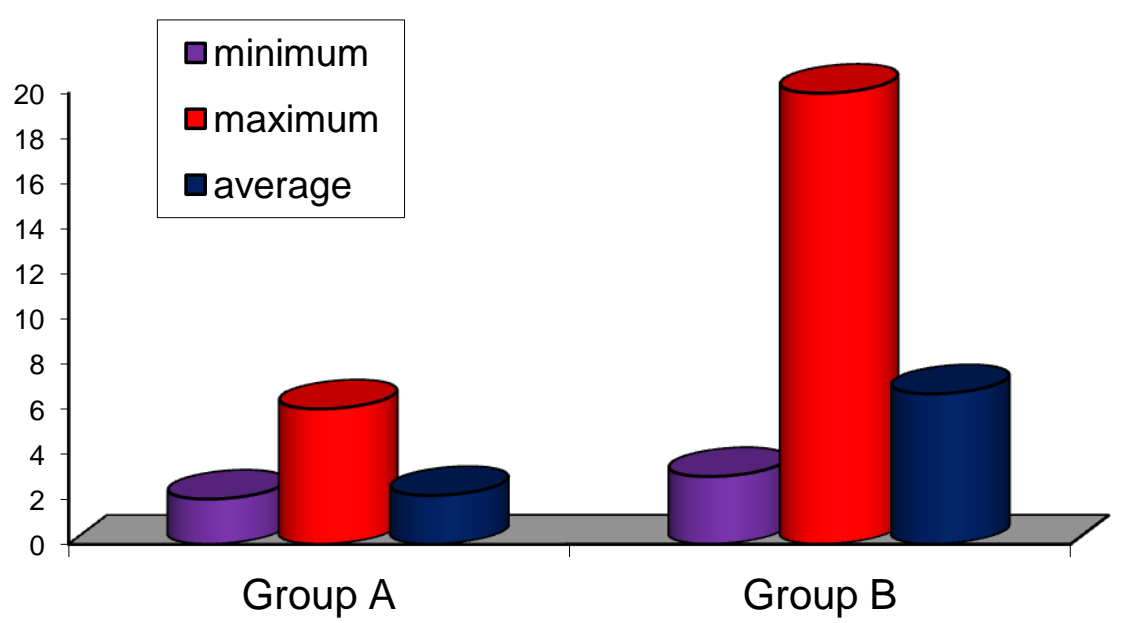

Graph 02 : Showing post operative pain in various Groups.

4 (Four) patients of group A (10.52\%) had wound infection while 15 patients of group B $(40.52 \%)$ had wound infection.

Table 03: Post operative wound infection in various groups

\begin{tabular}{|l|c|c|c|c|}
\hline Groups & Infection in patients & Total patients & Percentage & P value \\
\hline Group A & 4 & 38 & $10.52 \%$ & \\
\cline { 1 - 4 } Group B & 15 & 37 & $40.52 \%$ & 0.003 \\
\hline
\end{tabular}

Chi square

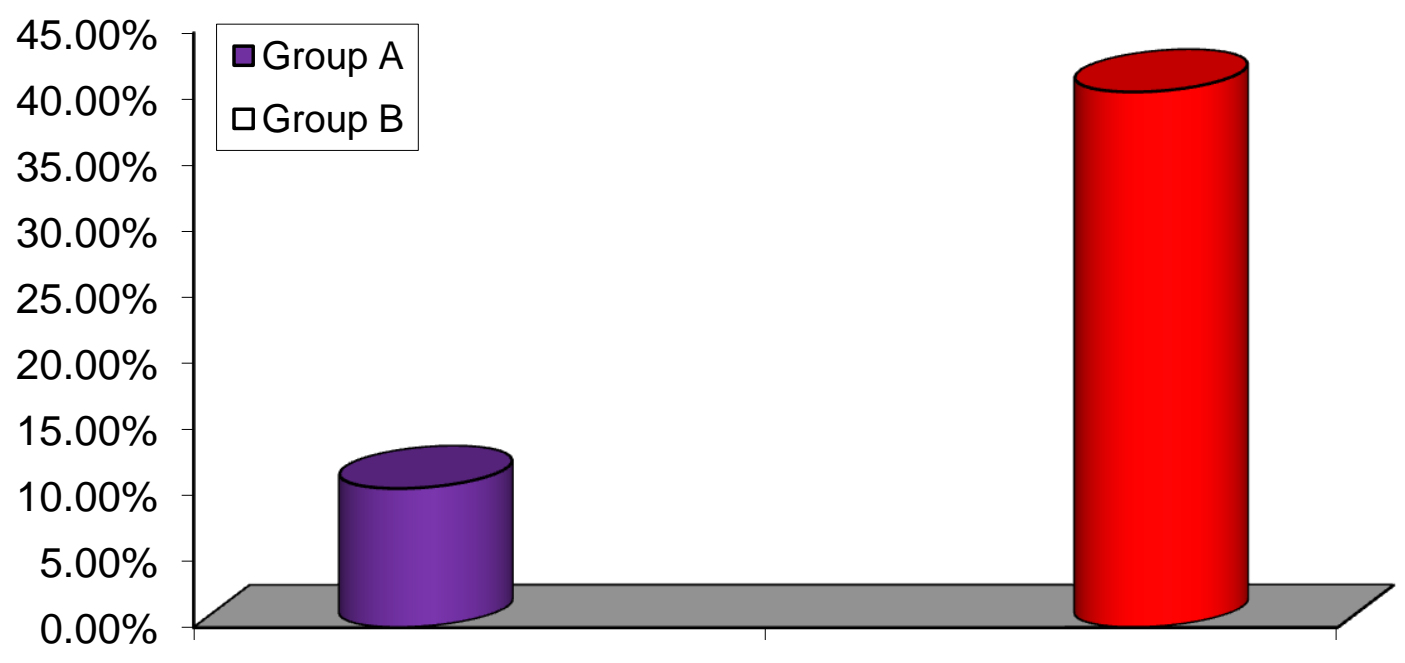

Graph 03: Showing rate of wound infection in various group

Post operative wounds in group A healed earlier in comparision to group B wounds $(28.55 \pm 5.717$ vs $48.54 \pm 12.43$ days, $\mathrm{P}=0.0001)$. 


\section{JMSCR Vol||04||Issue||12||Page 14999-15006||December}

Table 04: Post operative healing time of wound

\begin{tabular}{|l|c|c|c|c|c|c|c|}
\hline Groups & $\begin{array}{c}\text { Total } \\
\text { patients }\end{array}$ & $\begin{array}{c}\text { Minimum } \\
\text { healing time } \\
\text { (days) }\end{array}$ & $\begin{array}{c}\text { Maximum } \\
\text { healing time } \\
\text { (days) }\end{array}$ & $\begin{array}{c}\text { Mean healing } \\
\text { time } \\
\text { (days) }\end{array}$ & $\mathrm{Sd}$ & $\mathrm{T}$ & $\mathrm{P}$ value \\
\hline Group A & 38 & 21 & 42 & 28.55 & 5.717 & & \multirow{2}{*}{0.0001} \\
\hline Group B & 37 & 30 & 75 & 48.54 & 12.43 & 8.96 & 0.0001 \\
\hline
\end{tabular}

T test

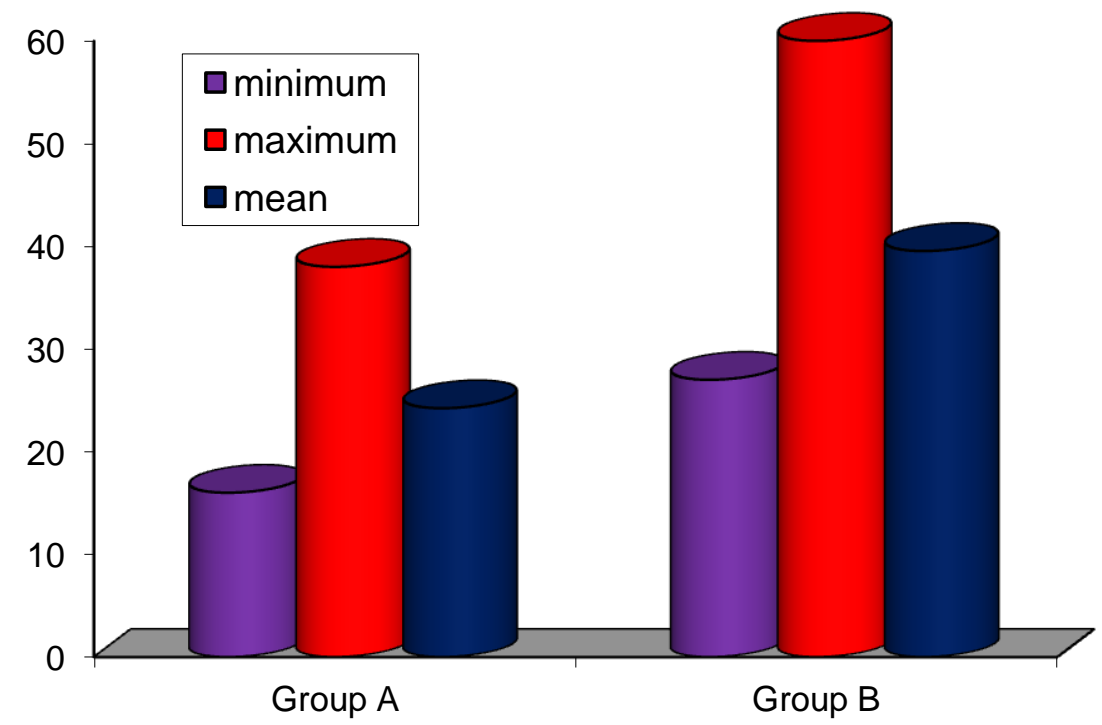

Graph 04: Showing healing time among various groups

The mean hospital stay of group A was $2.86 \pm$ 1.78 days, while for group $\mathrm{B}$ was $4.32 \pm 2.22$ days. There is statistically significant difference in hospital stay in both groups $(\mathrm{P}$ value $=0.03)$

Table 05: Hospital stay after procedure in various groups

\begin{tabular}{|l|c|c|c|c|c|c|}
\hline Groups & $\begin{array}{c}\text { Minimum } \\
\text { hospital stay }\end{array}$ & $\begin{array}{c}\text { Maximum } \\
\text { hospital stay }\end{array}$ & $\begin{array}{c}\text { mean hospital } \\
\text { stay (days) }\end{array}$ & SD & $\mathrm{t}$ & $\begin{array}{c}\mathrm{P} \\
\text { value }\end{array}$ \\
\hline Group A & 1 days & 9 days & 2.86 & 1.78 & \multirow{2}{*}{0} & \multirow{2}{*}{0.002} \\
\hline Group B & 1 days & 10 days & 4.32 & 2.22 & 3.14 & 0.022 \\
\hline
\end{tabular}

T test

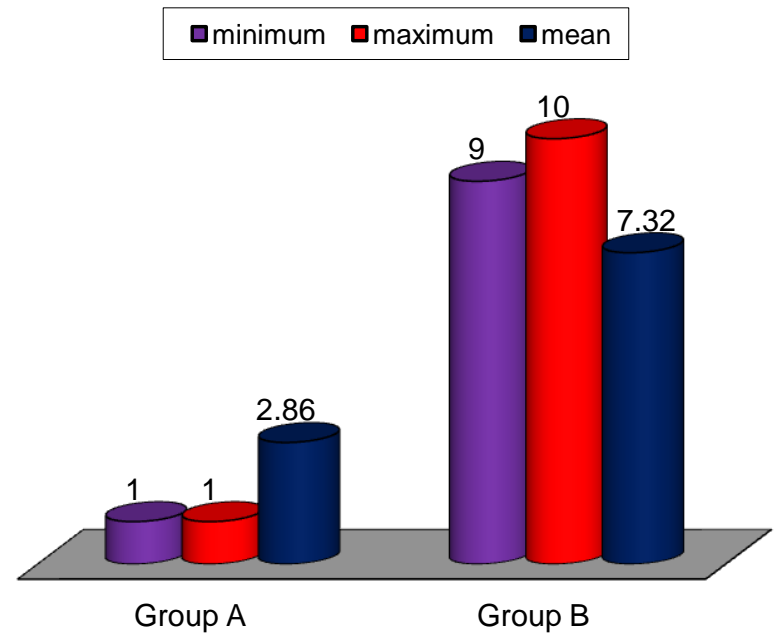

Graph 05: Showing postoperative hospital stay in studied groups.

No incidence of anal incontinence in both groups. 
Table 06 : Post operative anal incontinence among various groups

\begin{tabular}{|l|c|c|c|}
\hline Groups & Incontinence in patients & Total patients & Percentage \\
\hline Group A & 0 & 38 & $0 \%$ \\
\hline Group B & 0 & 37 & $0 \%$ \\
\hline
\end{tabular}

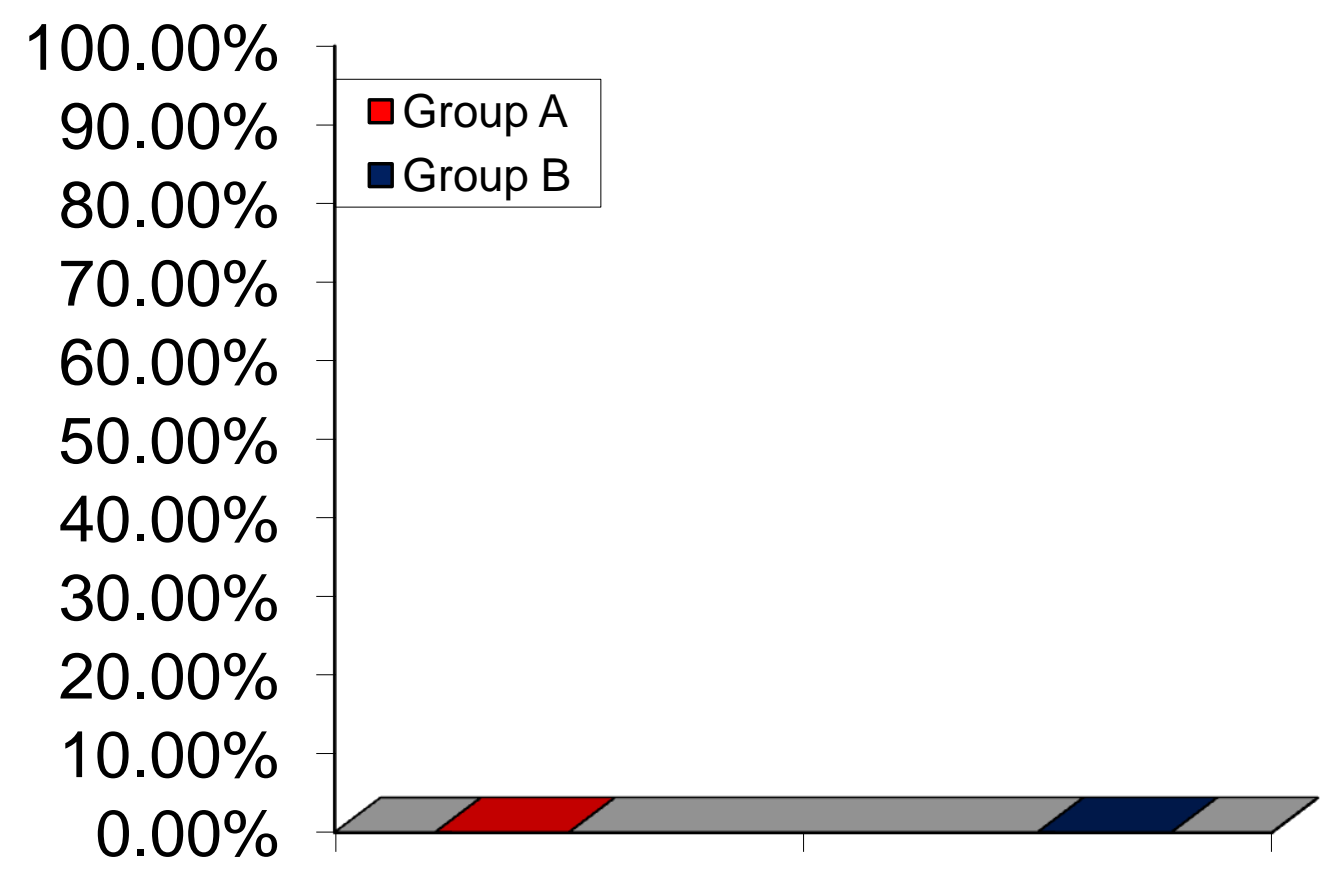

Graph 07 : Showing rate of incontinence in various groups

Recurrence developed in 2 patients out of 38 (5.3\%) of fistulotomy and 7 patients out of 37 (18.9\%) following fistulectomy.

Table 08: Post operative recurrence in various groups

\begin{tabular}{|l|c|c|c|c|}
\hline Groups & Recurrence in patients & Total patients & Percentage & P value \\
\hline Group A & 2 & 38 & $5.3 \%$ & \\
\cline { 1 - 4 } Group B & 7 & 37 & $18.9 \%$ & \multirow{2}{*}{0.069} \\
\hline
\end{tabular}

Chi square

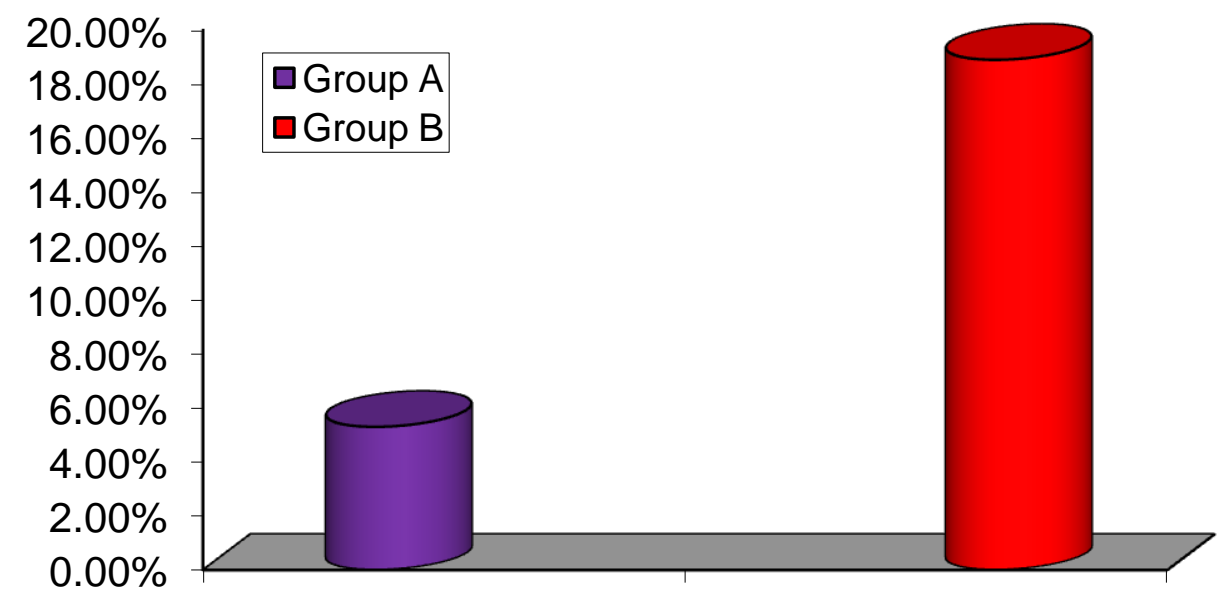

Graph 08 : Showing rate of recurrence in various groups. 


\section{JMSCR Vol||04||Issue||12||Page 14999-15006||December}

In group A, minimum time required is 6 days and maximum time required is 22 days, average time required is 10.55 days with mean $10.55 \pm 4.50$ days.
In group $\mathrm{B}$, minimum time required is 6 days and maximum time required is 90 days, average time required is 23.81 days with mean $23.81 \pm 21.46$ days. It is statistically significant distribution ( $\mathrm{p}$ value $=0.0004)$

Table 09: Return to routine work after surgery in various groups

\begin{tabular}{|l|c|c|c|c|c|c|c|}
\hline Groups & $\begin{array}{c}\text { Total } \\
\text { Patients } \\
\text { (n) }\end{array}$ & $\begin{array}{c}\text { Minimum } \\
\text { duration } \\
\text { (Days) }\end{array}$ & $\begin{array}{c}\text { Maximum } \\
\text { duration } \\
\text { (Days) }\end{array}$ & $\begin{array}{c}\text { Mean } \\
\text { (Days) }\end{array}$ & SD & $\mathrm{t}$ & $\mathrm{P}$ \\
\hline Group A & 38 & 6 & 22 & 10.55 & 4.50 & & \multirow{2}{*}{0.0004} \\
\hline Group B & 37 & 6 & 90 & 23.81 & 21.46 & 3.72 & 0.004 \\
\hline
\end{tabular}

t test

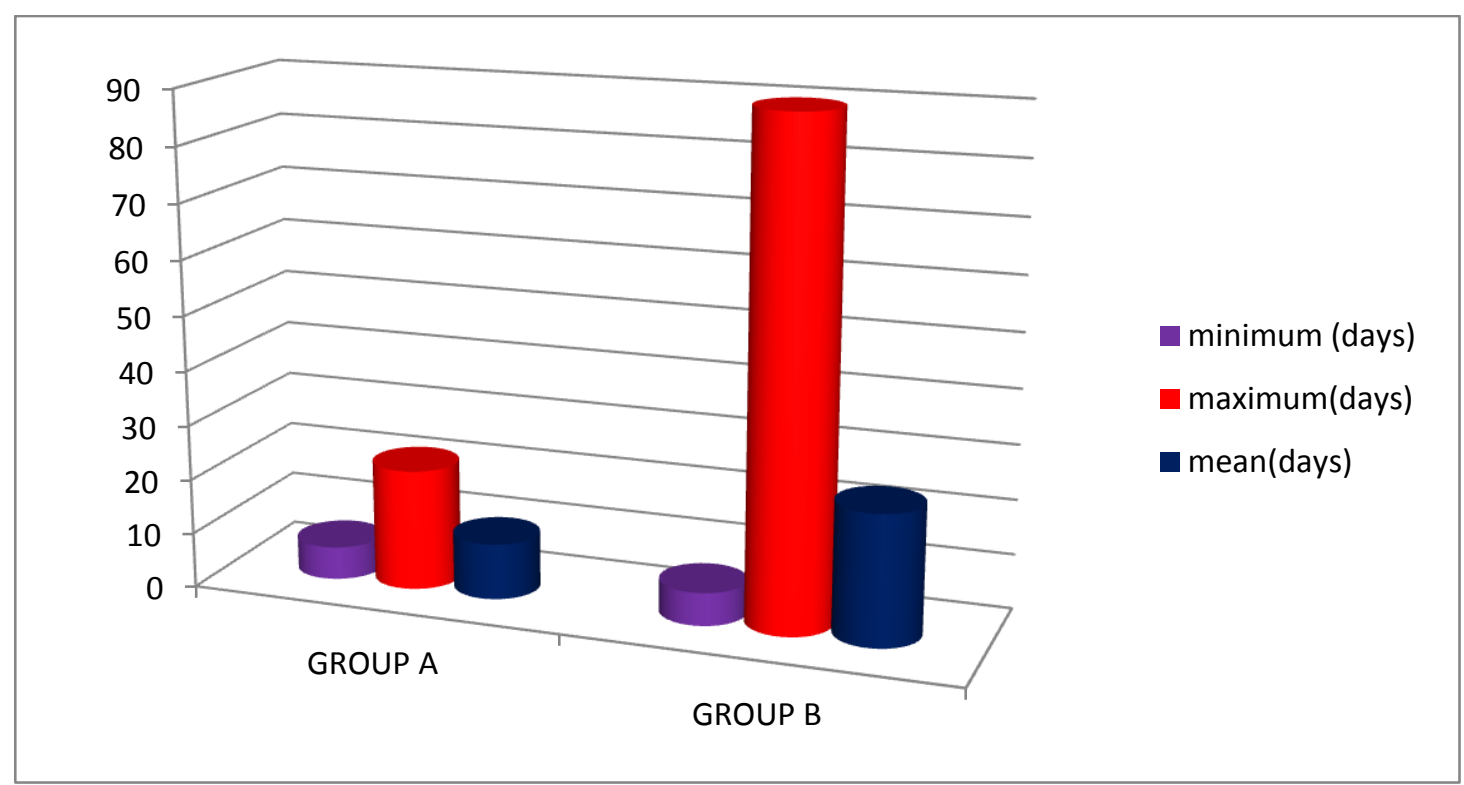

Graph 09 : Showing days required for returning to normal work among various groups

\section{Discussion}

In our study, the most common age group affected by fistula in ano found to be 31 to 50 years which coincides with most of studies. . In our study mean age in group A is $41.5 \pm 10.4$ years, while it is $45.2 \pm 12.3$ years in group B. There was no significant difference between 2 groups with respect of age $(\mathrm{p}$ value $=0.168)$. Buie 1960 quotes 42 years as the average age for Fistula-in-ano, after a study of 5325 cases. Fifty percent of cases were between 30 and 50 years of age.

In our study, the disease was prevalent in males. Group A (fistulotomy) consists of 31 male and 6 female whereas group B (fistulectomy)consists of 35 male and 3 females. Male to female ratio is 7.3: 1 . There is no statistically significant difference in the gender distribution ( $\mathrm{P}$ value $=0.268)$. In our study $88 \%$ are males which coincides with most of studies. Gabriels (1937) observed the preponderance of males over females in cases of fistula-inano in the proportion of 3:1. In 1957, Lockhart Mummery agreed with this observation. Buie (in 1960) showed males to make $68.8 \%$ of cases of fistula-in-ano. Khurana et al (1972) observed that $91 \%$ of their patients were males.

In our study, post operative pain period of fistulotomy was significantly less than that of fistulectomy, with mean duration of $2.6 \pm 10.2$ days for fistulotomy in comparison to mean duration of pain of $5.9 \pm 3.0$ days after fistulectomy (P value $=0.00$ ). Pain was categorized as mild, moderate and severe. In patients of fistulectomy around $70 \%$ patients had mild pain and $30 \%$ had moderate pain, while after fistulectomy around 
$60 \%$ patients had moderate pain and $40 \%$ had severe pain. All the patient after fistulotomy responded to simple analgesic like diclofenac sodium and that too is required for very short duration average of around 1 week. But many patients after fistulectomy required higher analgesics like tramadol that too for around 1 month, some.

In our study, wound infection is observed being significantly of shorter duration in fistulotomy group than in fistulectomy group ( $\mathrm{p}$ value $=0.003$ ). Most common complication after surgery was wound infection, it is very low after fistulotomy, occurring in only $10.5 \%$ but in about $40.5 \%$ after fistulectomy.

Time taken for wound to heal is minimum in patients of fistulotomy, with average duration of 28.5 days with mean $28.5 \pm 5.7$ days in comparison to average duration of 48.5days with mean $48.50 \pm 12.4$ days after fistulectomy which is statistically significant distribution( $\mathrm{p}$ value $=$ 0.0001). So more dressings were required, even after discharge in patients of fistulectomy. Kronborg who demonstrate a shorter healing times (34 days vs. 41 days) with fistulotomy compared to fistulectomy $(\mathrm{P}<0.02)$ in 47 randomized patients. Removal of complete track and adjacent tissue in fistulectomy results in larger wound, thus there is more risk of postoperative bleeding and pain with longer healing time(Anwar I,2003.

Anal incontinence is not seen in any patient after both procedures fistulotomy and fistulectomy. All those patients were kept in close follow up. None of the patients in either group was found to have anal incontinence during a follow-up period. This observation is logical as all the internal openings were located in the lower anal canal in our patients. In agreement with other randomized clinical studies (Lindsey et al., 2002; Jain et al., 2012).

Recurrence is least common after fistulotomy, occurring in only $5.26 \%$ while it occurred in about $18.91 \%$ after fistulectomy method, recurrences occurred in all the patients after 1 month and mainly between 1-6 months. The proportion comparison of Recurrence in patient of two groups do show any significant difference between them $(p>0.05)$. Kronborg reported that the recurrence rates following a fistulectomy and a fistulotomy were $9.52 \%$ and $12.5 \%$, respectively, during a follow-up period of 12 months. .Other study was conducted in North India between September 2008 through April 2010 on Forty patients with simple anal fistula, reported no case of recurrence and anal incontinence. (Jain et al)

\section{Conclusion}

Fistulotomy can be recommended as a standard surgical procedure in the treatment of low anal fistula for the merits of early wound healing, less post operative pain, lower rates of wound infection, early hospital discharge and lesser incidence of recurrence in comparison to that of fistulectomy.

\section{References}

1. Bacon.H.E, Stuart.T.Ross, and Porfiro Mayo Recro : Proctology, J.B. Lippincort Co. PP, 88-108, 1956.

2. Buie. L.A : Practical Proctology, $2^{\text {nd }}$ Edn. 1960.

3. Khurana, C., Saronwala, K. C. and Gupta, S. P.: Primary skin grafting after fistulectomy in the treatment of fistula in ano. Amer. J. Proctol., 23: 139-152, 1972.

4. Deshpande, P. J., Pathak, S. N., Sharma, B. N. and Singh, L. M.: Treatment of fistula in ano by Kshara Sutra. J. Res. Ind. Med., 2: 131-139, 1968.

5. Deshpande, P. J. Pathak and Sharma, K. R.: Non-operative ambulatory treatment of fistula in ano by a new technique. Review and follow-up of 200 cases. Amer. J. Proctol., 24: 49-60, 1973.

6. Gabriel, W. B'.: "The Principles and Practice of Rectal Surgery." 5th Edition. H. K. Lewis and Co. Ltd., London, 1963, pp. 6, 268, 289-313.

7. Kumar.R, Gupta.A.K, and Mathur.D : Anal fistula : A nonoperative method of 
treatment. A report of 100 cases. Indian journal of Surgery, 49 ; 239-243, july 1987.

8. Agarwal D, Arora D, Avasthi A and Singhal S .Scholars Journal of Applied Medical Sciences Sch. J. App. Med. Sci., 2014; 2(1B):202-204 (SJAMS) ;ISSN 2320-6691 (Online) ISSN 2347-954X (Print)

9. Kronborg O. To lay open or excise a fistula-in-ano: a randomized trial. $\mathrm{Br} \mathrm{J}$ Surg.1985;72:970. [PubMed]+

10. Athanasiadis S, Helmes C, Yazigi R, Köhler A, The direct closure of the internal fistula opening without advancement flap for transsphincteric fistulas-in-ano. Dis Colon Rectum. 2004 Jul;47(7):1174-80. Epub 2004 May 19.

11. Khurana, C., Saronwala, K. C. and Gupta, S. P.: Primary skin grafting after fistulectomy in the treatment of fistula in ano. Amer. J. Proctol., 23: 139-152, 1972

12. Imran Anwar, Zahid Niaz, Ahmad Muneeb, Khalid M Cheema, Amna Moeen. Fistulotomy a better treatment modality than Fistulectomy for low Fistulo in Ano.Ann King Edward Med Coll Apr Jun 2003;9(2):171-2.

13. Jain BK, Vaibhaw K, Garg PK, Gupta S, Mohanty D.J Korean Soc Coloproctol. 2012 Apr; 28(2): 78-82. Published online 2012

Apr

30. doi: $10.3393 / \mathrm{jksc} .2012 .28 .2 .78$

14. Bhatti Y, Fatima S, Shaikh GS, Shaikh S. Fistulotomy versus fistulectomy in the treatment of low fistula in ano.Rawal Medical Journal,PMAR;vol36,no4; octdec,2011;1-8. 